\title{
Review
}

\section{Role of insulin resistance in the pathogenesis of NIDDM}

\author{
H. Yki-Järvinen \\ Department of Medicine, University of Helsinki, Helsinki, Finland
}

The ability of body tissues to increase glucose uptake in response to a standardized, physiological dose of insulin varies at least fivefold, even in non-diabetic subjects (Fig. 1) [1]. This large variability in insulin sensitivity is of considerable interest as those with a blunted biological response to insulin have an increased risk for developing non-insulin-dependent diabetes mellitus (NIDDM) and its complications, especially macrovascular disease. This has been demonstrated in Native [2], Mexican [3, 4] and Japanese [5, 6] Americans, Nauruans [7] and Caucasians [8-11]. However, our understanding of the association between insulin resistance and NIDDM is far from complete. It is highly controversial whether insulin resistance, which appears necessary, although not sufficient, to cause NIDDM, is acquired, genetic, or genetic but mediated via known genetic causes of insulin resistance such as abdominal fat distribution [12]. This review will describe, first, the major causes of variation in insulin action in normal subjects. The purpose is to emphasize the need to quantitate and consider all such factors before attributing insulin resistance to 'new' causes such as smoking [13], hypertension [14] or a positive family history for NIDDM $[15,16]$. In the second part, the ability of chronic hyperglycaemia to cause insulin resistance ("the glucose toxicity concept'), and its implications for the pathogenesis and treatment of NIDDM will be reviewed.

Presented as the Minkowski Lecture, EASD meeting in Istanbul, Turkey, 1993

Corresponding author: Dr. H. Yki-Järvinen, The University of Texas Health Science Center at San Antonio, Department of Medicine, Division of Diabetes, 7703 Floyd Curl Drive, San Antonio, Texas 78284-7886, USA

Abbreviations: CT, Computerised tomography; MRI, magnetic resonance imaging; AV, arterio-venous; NIDDM, non-insulindependent diabetes mellitus; IDDM, insulin-dependent diabetes mellitus.

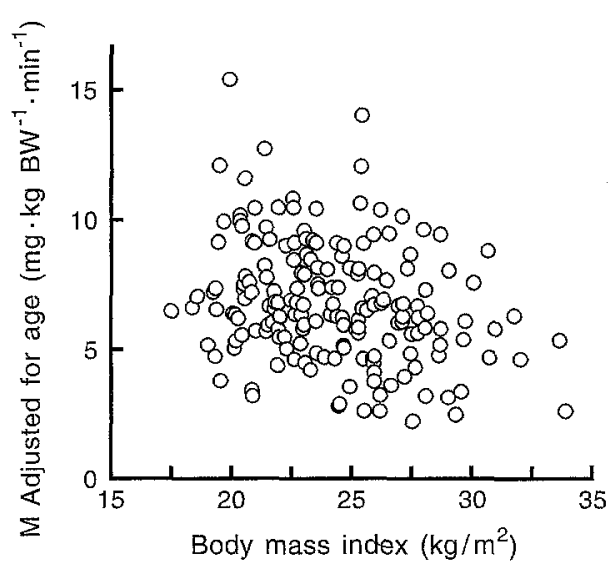

Fig. 1. Variation in insulin sensitivity in 177 Finns with normal fasting plasma glucose and glycated haemoglobin concentrations. Each subject received a euglycaemic hyperinsulinaemic insulin clamp (insulin infusion rate $1 \mathrm{mU} \cdot \mathrm{kg}^{-1} \cdot \mathrm{min}^{-1}$ ). The glucose infusion rate required to maintain normoglycaemia between 20-120 min was used as the measure of whole body insulin sensitivity. Unpublished data and data from references [25, 31, 105, 121-123]

\section{Variation in insulin action in normal subjects}

Simply knowing the age and degree of relative obesity (body mass index) is insufficient to explain more than $-35 \%$ of the variability in insulin action in normal people (Fig.1), even when insulin sensitivity is quantitated using the gold standard technique, the euglycaemic insulin clamp [17], in the same laboratory in one homogenous ethnic group such as the Finns (Fig. 1).

Physical fitness. The close correlation between maximal aerobic power $\left(\mathrm{VO}_{2} \max \right)$ and whole body insulin sensitivity is well known $[18,20]$, but often neglected [13-16]. For example, after considering $\mathrm{VO}_{2} \mathrm{max}$ as a confounding variable, no significant 

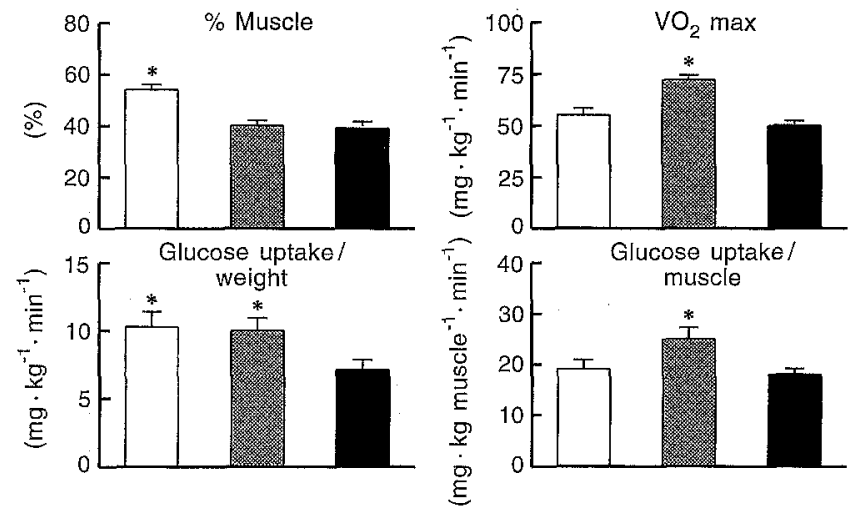

Fig. 2. Effect of body composition and maximal aerobic power on insulin sensitivity. The weight lifters ( $\square$ ) differ from the other two groups by their high percent muscle of body weight, while the runners (10) have a higher $\mathrm{VO}_{2} \max$ than either the weight lifters or the control subjects $(\boldsymbol{\square}){ }^{*} p<0.05$ or less vs other groups. Glucose uptake per $\mathrm{kg}$ of body weight (lower left panel) is increased in both weight lifters and runners compared to untrained subjects, while glucose uptake expressed per kg muscle tissue, is only increased in the runners. Adapted with permission from reference [25]

[21] or a marginally significant [22] deterioration in insulin action at physiological insulin concentrations was found in patients with essential hypertension in two recent studies (Fig. 2). Of course, hypertension per se might worsen $\mathrm{VO}_{2} \max$ and thereby insulin action, but these studies emphasize the need at least to consider known determinants of insulin sensitivity. Recently, it was also demonstrated that smokers are more insulin resistant than non-smokers [13]. Whether this is due to some component of cigarette smoke per se or to physical inactivity, which one intuitively might predict to be more frequent among smokers than non-smokers, remains to be tested. Regarding insulin resistance in relatives of patients with NIDDM, $\mathrm{VO}_{2}$ max has been measured in two studies $[23,24]$. In the Pima Indians, insulin resistance appears familial and independent of physical fitness [23] while in a recent study in Caucasians [24], relatives of patients with NIDDM were not resistant after controlling for physical fitness. These data suggest that one may have to reconsider the idea that insulin resistance is a familial or genetic trait independent of physical fitness in NIDDM.

Body composition. Since muscle tissue is the major target for insulin-stimulated glucose disposal, a high muscle mass enhances glucose utilization [25] and glucose tolerance [26] independent of physical fitness (Fig. 2). To control for this confounding variable in studies aimed at defining primary defects in NIDDM, the fat free or muscle mass should be determined.

Gender. Women have a lower incidence of cardiovascular disease than men [27], and also typically have, during the fertile age, lower serum triglyceride and uric acid concentrations, a higher serum $\mathrm{HDL}_{2}$ cholesterol concentration and a lower waist-to-hip ratio compared to men [28-30]. These changes are all indicative of enhanced insulin sensitivity in women. However, two confounding factors have to be considered when comparing insulin sensitivity between men and women. First, women have a greater relative fat mass and lower muscle mass than men, and women also have on the average an approximately $20 \%$ lower $\mathrm{VO}_{2} \max$ than men $[31,32]$. If equally fit men and women are compared and glucose uptake determined directly in skeletal muscle, women are more sensitive to insulin [33]. Because of the difference in body composition, rates of glucose uptake are similar between equally fit men and women if expressed per $\mathrm{kg}$ of body weight [31]. The gender difference in insulin sensitivity appears to be explained by sex steroid levels although it has been difficult to establish causality in human studies. In rats, ovariectomy induces insulin resistance in skeletal muscles which is restored by oestrogen replacement [34]. Treatment of female rats with testosterone using doses which increase serum testosterone concentrations in female rats to concentrations found in normal male rats causes insulin resistance, and changes in muscle morphology such as decreases in capillary density and insulin-sensitive muscle fibre types [35].

Obesity. Obese subjects have a greater fat mass and lean body mass than non-obese subjects [36]. Because muscle cells do not multiply, the increase in lean body mass involves muscle cell hypertrophy and a decrease in muscle capillary density [37]. Obese individuals also have a greater percent of glycolytic insulin-resistant fibres and a lower percent of oxidative insulin-sensitive fibres [36, 38]. Whether these morphological changes are causes or consequences [39] of hyperinsulinaemia in the obese is presently unclear. However, it appears clear that the cellular (extraction of glucose) rather than the vascular (inability of insulin to reach muscle cells or to stimulate muscle blood flow) defect appears to be rate-limiting for insulin stimulation of glucose uptake, because glucose uptake is markedly reduced in obese subjects even under conditions where the interstitial insulin concentrations are higher in obese than in non-obese subjects [40].

Intra-abdominal fat. Since the pioneering studies of J. Vague [41], fat distribution has been known to influence glucose tolerance and insulin sensitivity independent of overall adiposity $[29,42]$. The amount of intra-abdominal fat seems to be the critical determinant of the impact of regional adiposity on glucose metabolism. Both hepatic glucose production and peripheral glucose utilization are more resistant to insulin in upper than lower body obesity [42]. Omental fat 


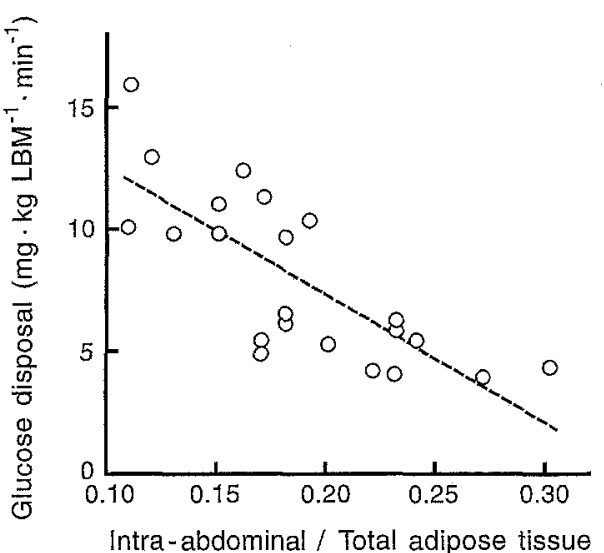

Fig. 3. Relationship between ratio of intra-abdominal vs total fat, as determined by MRI scanning, and whole body insulin sensitivity in normoglycaemic black men with NIDDM. Adapted with permission from reference [49]

cells mobilize more non-esterified fatty acids than subcutaneous fat cells, possibly due to greater $\beta_{3^{-}}$ and decreased $\alpha_{2}$-adrenoreceptor function [43]. The ensuing greater hepatic resistance induces hyperinsulinaemia both by reducing hepatic insulin clearance and sensitivity $[42,44]$. Hyperinsulinaemia itself is able to induce both insulin resistance [45], and an insulin-resistant fibre type [39] in skeletal muscle. Overfeeding experiments in identical twins suggest that regional fat deposition is under strong genetic control [12]. Populations with a high prevalence of NIDDM such as the Pima Indians [46], Mexican Americans [47] and Japanese Americans [6] all have a higher prevalence of abdominal obesity and a greater degree of insulin resistance $[3,6,48]$ than Caucasians. Since the ratio of intra-abdominal/total fat mass, especially when determined by computerised tomography (CT) [49] or magnetic resonance imaging (MRI) [50] scanning, is highly inversely correlated with insulin sensitivity (Fig.3), one may ask whether the differences in regional fat distribution, obesity and physical fitness could account for racial differences in insulin sensitivity.

\section{Location of defects in insulin action in vivo}

Under basal and postprandial hyperglycaemic conditions, the absolute rate of glucose utilization is normal in NIDDM [51] because hyperglycaemia compensates by glucose mass-action for peripheral insulin resistance [1], and hyperglycaemia can be attributed to excessive basal hepatic glucose production and its impaired suppression postprandially [52, 53]. However, if glucose uptake is measured under conditions where glucose and insulin concentrations are identical in non-diabetic and diabetic individuals, a major defect in glucose uptake is observed. The ensuing discussion is focused on critically examining at-

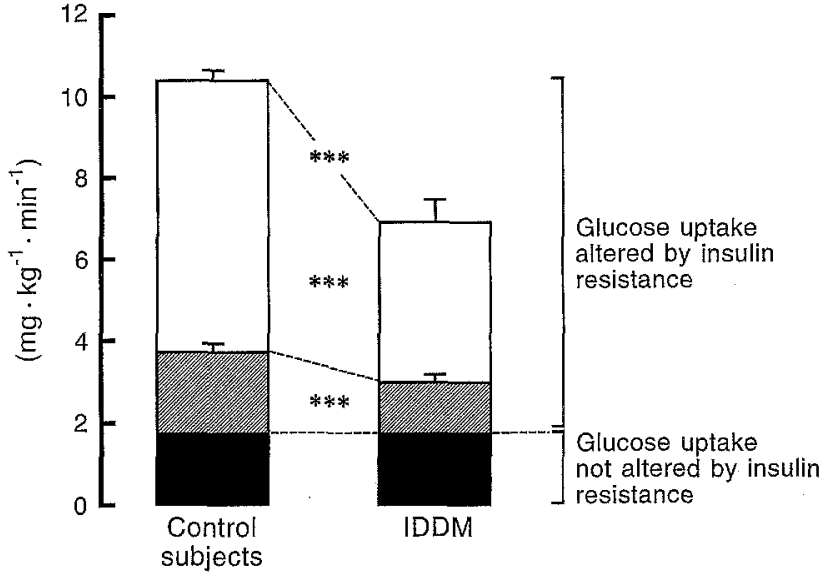

Fig.4. Components of glucose uptake. During hyperinsulinaemia (serum insulin $\sim 100 \mathrm{mU} / \mathrm{l}$ ), the component of glucose uptake not altered by insulin resistance ( $\boldsymbol{\omega}$ ) includes non-insulin-dependent glucose oxidation, such as that which occurs in the brain $\left(\sim 1 \mathrm{mg} \cdot \mathrm{kg}^{-1} \cdot \mathrm{min}^{-1}\right)$ [55-58], and insulin-sensitive glucose oxidation which does not become insulin resistant such as that which occurs in the heart $\left(-0.5 \mathrm{mg} \cdot \mathrm{kg}^{-1} \cdot \mathrm{min}^{-1}\right)$ [62]. The other component of glucose uptake, which is altered by insulin resistance includes non-oxidative glucose disposal [59], and some fraction of oxidative glucose disposal (the sum of the black and the hatched bars). Data for control subjects and IDDM patients adapted with permission from reference [73]. *** $p<0.001$

tempts to localize the defect in glucose utilization to non-oxidative (predominantly glucose storage) and oxidative pathways of glucose metabolism.

Glucose oxidation and storage. In vivo, the rate of glucose utilization is commonly determined using the euglycaemic insulin clamp technique combined with an infusion of $\left[3-^{3} \mathrm{H}\right]$ glucose [54]. If glucose oxidation is simultaneously determined using indirect calorimetry, the rate of non-oxidative glucose disposal can be calculated by subtracting the rate of glucose oxidation from total glucose utilization [54]. One may then calculate the percent of total glucose utilization that is disposed oxidatively and non-oxidatively. When such calculations are applied to compare insulin-resistant individuals and normal subjects, it is usually found that the rate of non-oxidative glucose disposal, a measure of glycogen synthesis (glucose storage), is more reduced than the oxidative component [15]. Such findings have been interpreted to indicate that insulin resistance is localized to pathways of glycogen synthesis. However, three factors need to be considered before dogmatically accepting this conclusion. First, glucose oxidation includes a fixed non-insulin-dependent component (brain glucose oxidation, [55-58]) while non-oxidative glucose disposal during hyperinsulinaemia closely parallels insulin-sensitive glucose storage [59]. Second, insulin-sensitive glucose oxidation includes an appreciable component (heart glucose oxidation, $[60,61]$ ) which does 


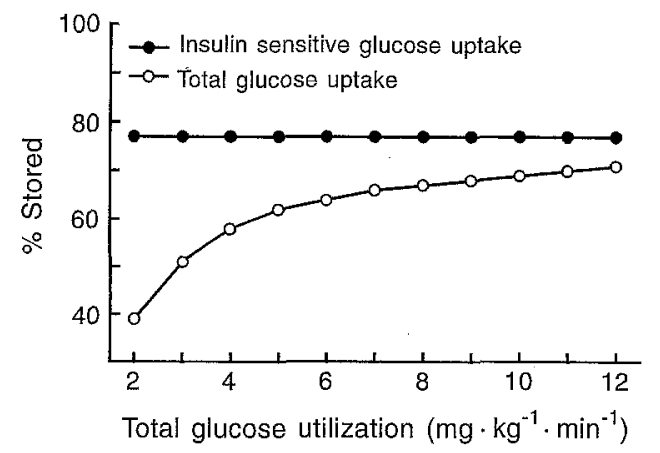

Fig. 5. Percent of glucose stored calculated from insulin-sensitive glucose uptake (- - ) and from total glucose uptake $\left(-\mathrm{O}_{-}\right)$. If calculated by dividing the rate of glucose oxidation by total glucose disposal without considering the component of glucose oxidation that is not decreased by insulin resistance, the percent glucose stored will decrease as a function of total glucose uptake even if it is constant, as assumed in this example. Adapted with permission from reference [64]

not seem to become insulin-resistant [21, 62]. These two fixed components decrease the relative amount of glucose stored in insulin-resistant individuals even when the relative reductions in glucose oxidation and storage are similar (Figs. 4 and 5). Third, when glucose uptake is determined at high physiological insulin concentrations, glucose oxidation is quantitatively less important than glucose storage. The likelihood of missing a defect in glucose oxidation is therefore greater for glucose oxidation than storage. The net effect of these three factors is that glucose storage will always be more affected in insulin-resistant individuals, and that the likelihood of detecting a defect in insulin-stimulated glucose oxidation is much lower than that of detecting a defect in non-oxidative glucose disposal.

To more reliably estimate the contribution of defects in glucose oxidation and storage to decreases in whole body glucose disposal, the fraction of glucose oxidation which is either insulin-independent or not affected by insulin resistance, needs to be estimated. One possibility is to determine glucose oxidation in the basal state, and consider this rate to represent non-insulin-dependent glucose oxidation [63, 64]. This approach has two limitations. First, a small proportion of basal glucose oxidation is insulin-dependent [65], and second, the presence of insulin-sensitive glucose oxidation, which is not influenced by insulin resistance will be neglected. Even so, by subtracting basal glucose oxidation from glucose oxidation during hyperinsulinaemia, Del Prato et al. [63] found that the percent of glucose oxidized and stored of total glucose disposal was similar between patients with NIDDM and control subjects. The best way theoretically is to measure glucose oxidation directly using local indirect calorimetry across muscle tissue, which is the quantitatively most important location for insulin-stimulated glucose utilization [54].
Using this technique, Kelley et al. [19] found that patients with NIDDM oxidized $50 \%$ less glucose than matched non-diabetic subjects under normoglycaemic hyperinsulinaemic conditions. This relative reduction in glucose oxidation is appreciably higher than that found in studies using indirect calorimetry $[15,59,66]$. In insulin-dependent (IDDM) patients, the percent glucose oxidized and stored is similar to that in non-diabetic patients, assuming brain glucose oxidation to be $1 \mathrm{mg} \cdot \mathrm{kg}^{-1} \cdot \mathrm{min}^{-1}$, and heart glucose uptake $\left(0.5 \mathrm{mg} \cdot \mathrm{kg}^{-1} \cdot \mathrm{min}^{-1}\right.$, [62] $)$ to consist of glucose oxidation [60]. These data imply that there is a need to reconsider the glycogen synthetic pathway as the predominant location of insulin resistance. Of course, even if the percent of glucose oxidized and stored is similar in insulin-resistant and sensitive individuals, this does not exclude the possibility that defects along the glycogen synthetic pathway cause insulin resistance, but does indicate that such a defect will induce a rate-limiting defect at the level of glucose transport or phosphorylation.

Glucose extraction and blood flow. Limb glucose uptake can be determined using the Fick principle by multiplying the glucose arterio-venous (AV) difference by blood flow. In normal subjects, insulin rapidly increases the glucose AV-difference, a measure of cellular glucose extraction, to its maximum (Fig. 6) [67]. Insulin also increases blood flow but this effect of insulin differs from stimulation of glucose extraction in two important ways. First, stimulation of blood flow requires higher, supraphysiological plasma insulin concentrations than stimulation of glucose extraction [68, 69], (Fig.6). Second, the response of blood flow to insulin is gradual and reaches maximum after several hours of insulin stimulation, while glucose extraction is maximal within 30 to $90 \mathrm{~min}[68,69]$. Based on this physiological knowledge, one may predict that variation in insulin action in normal subjects is more likely to be attributable to blood flow at supraphysiological than physiological insulin concentrations while differences in glucose extraction distinguish between sensitive and insensitive individuals under physiological conditions. Abundant experimental evidence indicates that this indeed is the case. Thus, defects in insulin action on blood flow have been described in both obese subjects [68], and patients with IDDM [70], NIDDM [71] and essential hypertension [72], when glucose uptake has been measured during high-dose insulin infusions lasting up to $9 \mathrm{~h}$. On the other hand, during short-term insulin infusions lasting $2-3 \mathrm{~h}$, defects in glucose uptake are due to defects in glucose extraction in obese subjects [40], and patients with IDDM [73], NIDDM [74, 75] and essential hypertension [76].

A fundamental question regarding defects in insulin stimulation of blood flow is whether such defects are indeed responsible for the decrease in glucose up- 

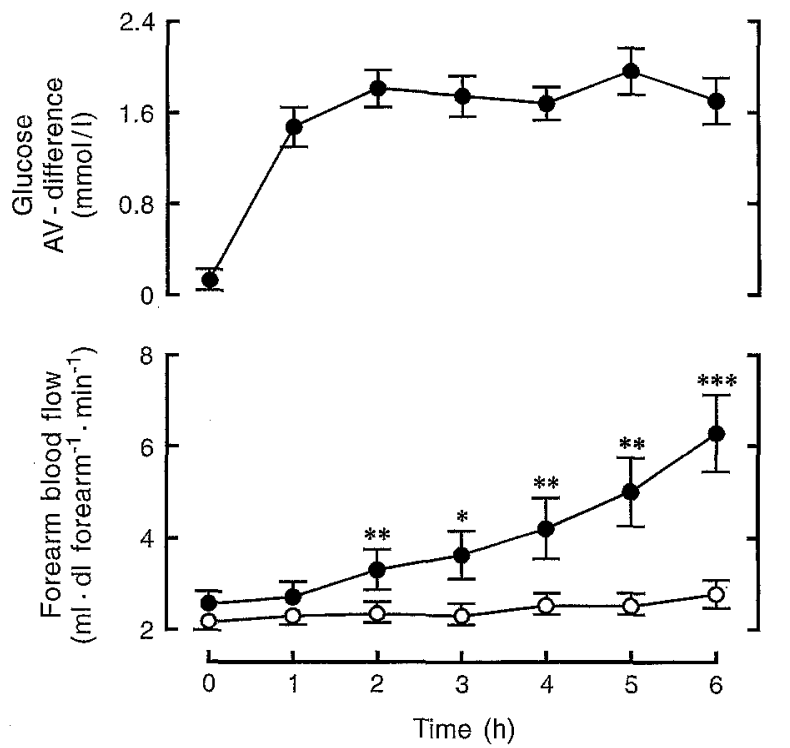

Fig. 6. The glucose AV-difference (glucose extraction) and forearm blood flow plotted as a function of time during three sequential intravenous insulin infusions $(2 \mathrm{~h}$ each, serum insulin 61,139 and $462 \mathrm{mU} / \mathrm{l}$ ). Adapted with permission from reference [69]. * $p<0.05$; ** $p<0.01 ; p<0.001$ vs $0-1 \mathrm{~h}$ (basal)

take. Data addressing this question are controversial. Baron et al. [77] infused metacholine into the femoral artery of healthy volunteers and observed significant increases in both blood flow and leg glucose uptake. In contrast, Natali et al. [78] infused adenosine into the brachial artery but found no enhancement in glucose uptake despite a significant increase in blood flow. In this study, the increase in flow was entirely counterbalanced by a significant decrease in the glucose AV-difference.

\section{Is there a familial or genetic defect in insulin action in relatives of patients with 'common' NIDDM?}

A positive family history is the single most important factor, independent of physical fitness and obesity, in determining susceptibility to NIDDM $[10,46,79-$ 82]. It has recently been proposed, in cross-sectional studies, that individuals with a positive family history for NIDDM are more insulin resistant than those with a negative family history, and that insulin resistance may be genetically determined in such individuals [15, 83-85]. Some potential shortcomings of these studies should be considered before pursuing the hypothesis that insulin resistance is the primary abnormality predisposing to NIDDM. The studies included a small number of relatives (13 to 20), and in none of the studies were all parameters, especially intra-abdominal fat and maximal aerobic power, which profoundly influence insulin action in normal subjects, determined. This would seem important particularly when a small number of subjects is studied, to accurately control for known causes of variation in insulin action, and to avoid recruitment bias. Furthermore, in the study in which identical twins discordant for NIDDM were studied, an insulin secretory defect and normal insulin sensitivity was found in twins with normal glucose tolerance [84]. Insulin sensitivity was impaired only in the twins with impaired glucose tolerance [84]. In a recent study by Banerji et al. [49], where intra-abdominal fat mass was determined using CT scanning in normoglycaemic black NIDDM men, whole body insulin sensitivity was strongly inversely ( $r=-0.81$ ) related to intra-abdominal fat (Fig. 3) but not to body mass index or adipose tissue volume, and only weakly related to the waistto-hip ratio $(r=-0.49)$. It was proposed that insulin resistance in black NIDDM men is exclusively a consequence of increased intra-abdominal adipose tissue mass. In Pima Indians [23], insulin resistance is a familial characteristic which is not explained by gender, age, body mass index or physical fitness. The Pima Indians, who have the highest prevalence of NIDDM in the world [86], are more insulin resistant than Caucasians [48]. However, when determined using the waist-to-thigh circumference as a measure of abdominal obesity, the Pima Indians are also more abdominally obese than the Caucasians [48]. It is unclear to what extent intra-abdominal fat mass, if quantitated by some direct method, would explain insulin resistance in this population. The Mexican Americans $[3,4]$ who have a negative family history of NIDDM are equally as sensitive to insulin as Caucasians matched for age, weight, gender and intra-abdominal obesity, as measured by MRI scanning [87]. Whether the same would be true for Mexican Americans who have a positive family history of NIDDM is presently unknown.

Another argument, not explored in detail here, which questions the role of insulin resistance as a primary genetic defect in the pathogenesis of NIDDM, is the evidence gathered in over 20 prospective studies. These studies have demonstrated that insulin resistance only predicts NIDDM in individuals with a low acute insulin response [8, 9, 81, 88-90], even in extremely insulin-resistant populations such as the Pima Indians [89]. Furthermore, in prospective studies both insulin resistance $[3,4,6,8-10,79,81,89$ 92], and markers of insulin resistance such as obesity $[7,9,10,81,82,88-100]$, abdominal fat distribution $[4,6,89,94]$, physical inactivity $[80,81,95,97,99]$, a low sex-hormone-binding globulin concentration $[4$, 92] and macrovascular disease [81, 90], as well as insulin-secretory defects $[5,8,9,81,88,89,91]$ have predicted NIDDM.

A problem in the prospective studies is that insulin secretory defects can only be accurately compared between two groups if the groups are matched for factors which affect insulin secretion. Since subjects who develop NIDDM are usually more obese, physi- 


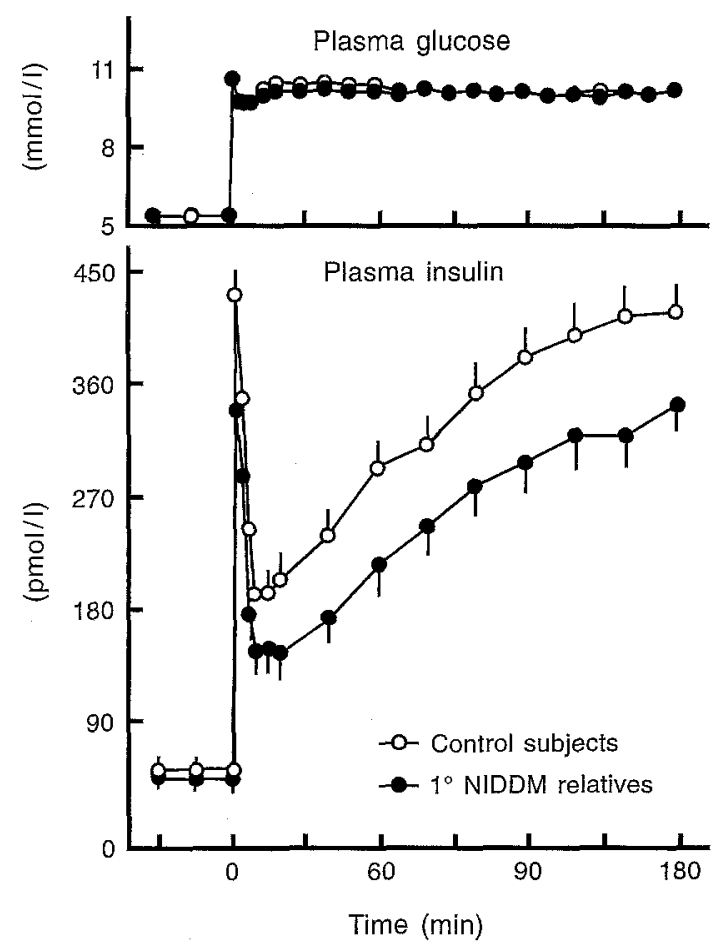

Fig. 7. Plasma glucose (top) and insulin (bottom) concentrations in hyperglycaemic clamp experiments in 100 normal volunteers of European ancestry. Reproduced with permission from reference [101]

cally inactive and insulin resistant than those who do not, comparison of insulin secretion has to be done using statistical procedures that adjust for differences between individuals with and without a positive family history. This approach is unlikely to be as accurate as study of carefully matched groups, because it assumes a linear relationship between insulin secretion and sensitivity. In a recent cross-sectional study, which included 100 volunteers of European ancestry, individuals with and without a first-degree NIDDM relative were carefully matched for age, body mass index, gender and the waist-to-hip ratio. It was found that those with a positive family history for NIDDM were equally sensitive as those with a negative family history, but had diminished first and second phase insulin release as determined by the hyperglycaemic clamp technique (Fig. 7) [101]. Even these data should be interpreted with caution. First, in Caucasians, patients with late-onset IDDM may erroneously be classified as having NIDDM [102]. Second, the matching of study subjects makes insulin resistance look unimportant in the pathogenesis of NIDDM although it clearly is an important risk factor for developing NIDDM, according to the prospective studies. Third, even in this study abdominal fat mass and $\mathrm{VO}_{2}$ max were not determined. This may, however, be of lesser concern than in the previous studies $[15,84,85]$ since a large number of subjects was studied and no difference in insulin sensitivity was found.
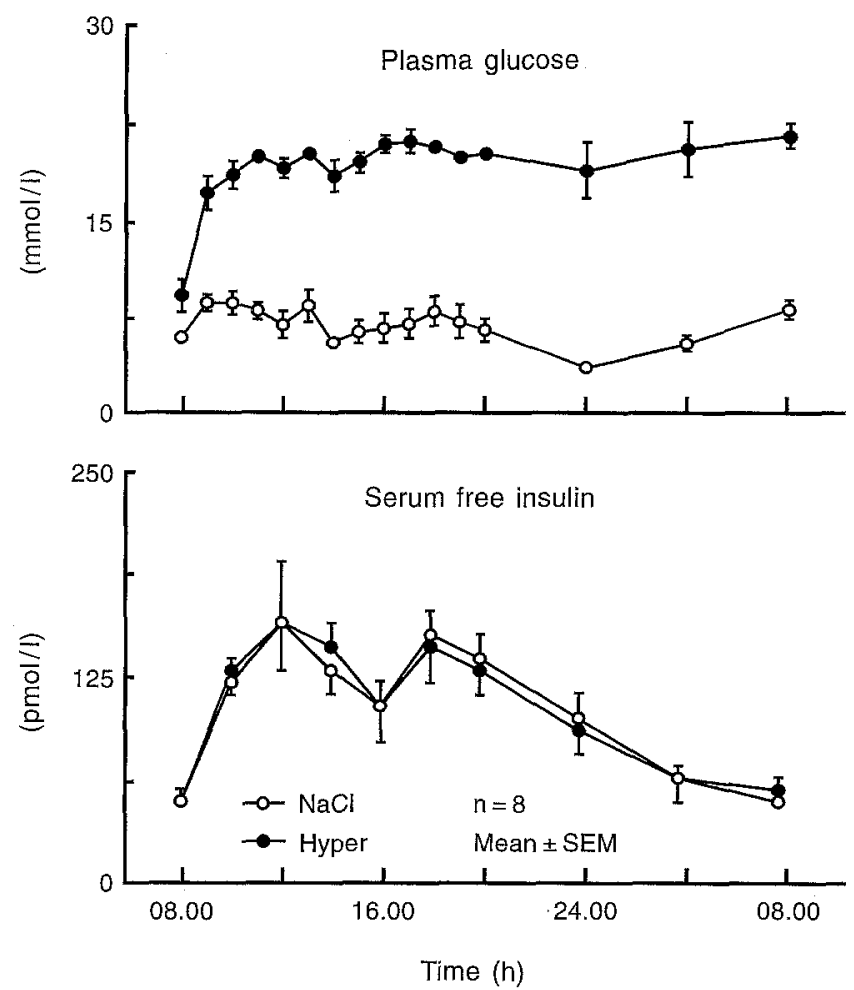

Fig. 8. Diurnal plasma glucose and insulin concentrations in studies where eight IDDM patients received identical diet and insulin dose on two study occasions. On one occasion, saline $(\mathrm{NaCl})$ was infused, on the other $10 \%$ glucose was infused to increase plasma glucose to $\sim 17 \mathrm{mmol} / \mathrm{l}$. The following day (Fig. 9), forearm glucose uptake was determined under similar conditions of glycaemia and insulinaemia. Reproduced with permission from reference [116]

\section{Glucose toxicity - the common acquired cause of insulin resistance in IDDM and NIDDM}

In any type of diabetes, NIDDM [103], IDDM [104, 105 ] or pancreatogenic [106], insulin sensitivity is impaired compared to matched non-diabetic individuals. In patients with IDDM, insulin sensitivity is normal if glycaemic control is normal, as in patients who are in clinical remission [107], or in whom glycaemic control has been normalized by intensive insulin therapy [108-110]. The normalization of insulin sensitivity during intensive insulin therapy is observed in the face of unchanged or diminished insulin requirements and free insulin concentrations [108-110] suggesting that factors other than insulin deficiency contribute to normalization of insulin sensitivity. In patients with NIDDM, any intervention which lowers plasma glucose concentrations seems to improve insulin sensitivity [111]. The degree of insulin resistance is inversely correlated with average glycaemic control in both patients with NIDDM $[2,112,113]$ and IDDM $[105,114]$. Direct proof of the ability of hyperglycaemia per se to induce insulin resistance has been obtained in studies in patients with IDDM $[115,116]$ as well as in studies performed in diabetic 

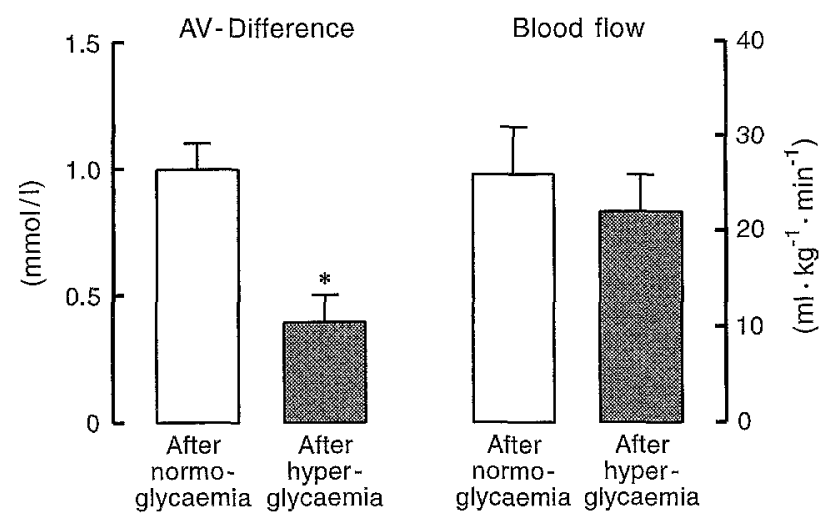

Fig.9. Forearm glucose AV-difference and blood flow after $24 \mathrm{~h}$ of hyperglycaemia and after $24 \mathrm{~h}$ of normoglycaemia (see Fig. 8). Exposure to hyperglycaemia decreased forearm glucose uptake significantly due to a decrease in glucose extraction ( $* p<0.05$ for hyper-vs normoglycaemia)

rats $[117,118]$. In IDDM, simply increasing the glucose concentration for $24 \mathrm{~h}$ is sufficient to induce insulin resistance in skeletal muscle $[115,116]$ (Figs. 8 and 9). In mildly diabetic rats, selective treatment of hyperglycaemia with phlorizin, which normalizes plasma glucose concentrations without changing plasma insulin concentrations, via inhibition of glucose reabsorption in the proximal tubuli, normalizes insulin sensitivity [117] and secretion [118]. The ability of hyperglycaemia itself to impair both insulin sensitivity and secretion has been referred to as 'glucose toxicity' $[1,111,119]$.

The glucose toxicity concept has widespread implications for both the pathophysiology and treatment of NIDDM. First, as hyperglycaemia itself self-perpetuates the diabetic state, it may significantly contribute to the natural course of NIDDM, which is characterized by gradual loss of insulin secretion and progressive impairment in insulin sensitivity [2]. Furthermore, hyperglycaemia might also contribute to the transition from impaired to diabetic glucose tolerance.

Regarding treatment of hyperglycaemia, it is wellestablished that every intervention be it diet, weight loss, inhibition of glucose absorption by acarbose or hepatic glucose production by metformin, stimulation of insulin secretion by sulfonylureas improves both glycaemia and insulin sensitivity [111]. Since glycaemia itself is a determinant of insulin sensitivity, concepts such as the existence of direct extrapancreatic effects of antihyperglycaemic agents can be questioned. Indeed, the current consensus seems to be that such direct effects are unlikely to be of clinical significance [120].

\section{Conclusion}

The above discussion illustrating the multitude of variables which influence insulin sensitivity in normal subjects challenges the prevailing view that insulin sensitivity is genetically determined in patients with NIDDM. The lack of accurate quantitation of all determinants of insulin sensitivity in the cross-sectional studies, and the difficulty in distinguishing between insulin secretion and sensitivity in prospective studies implies that the inherited metabolic abnormality in NIDDM still remains to be defined. The methodological difficulties in assessing the fate of glucose in many insulin-resistant states raise the possibility that defects in glycogen synthesis may not be rate-limiting for insulin action. It seems more likely that defects in glucose transport or phosphorylation are rate-limiting for glucose disposal, and thus represent either the primary regulatory steps or the steps via which distal defects signal their influence on glucose uptake.

The above considerations should not be interpreted to suggest that insulin resistance is unimportant in the pathogenesis of NIDDM. It clearly increases the risk of developing NIDDM, and more importantly, its early amelioration by lifestyle modification seems sufficient to prevent NIDDM [81].

Acknowledgements. This Minkowski lecture is a tribute to the late Professor Esko Nikkilä, M.D., the founder of clinical research in the field of glucose and lipoprotein metabolism at the University of Helsinki in Finland. The author also gratefully acknowledges the help of numerous collaborators, both abroad and in Finland, for their invaluable help in the studies addressing the acquired causes of insulin resistance, as well as the financial support from the Academy of Finland.

\section{References}

1. Yki-Järvinen H (1990) Acute and chronic effects of hyperglycemia on glucose metabolism. Diabetologia 33: 579585

2. Lillioja S, Mott DM, Howard BV et al. (1988) Impaired glucose tolerance as a disorder of insulin action: longitudinal and cross-sectional studies in Pima Indians. $\mathrm{N}$ Engl J Med 318: 1217-1225

3. Haffner SM, Stern MP, Mitchell BD, Hazuda HP, Patterson JK (1990) Incidence of type II diabetes in Mexican Americans predicted by fasting insulin and glucose levels, obesity and body-fat distribution. Diabetes 39: 283-288

4. Haffner SM, Valdez RA, Morales PA, Hazuda HP, Stern MP (1993) Decreased sex hormone-binding globulin predicts noninsulin-dependent diabetes mellitus in women but not in men. J Clin Endocrinol Metab 77: 56-60

5. Hara H, Miyauchi A, Okamura M, Ishida S, Egusa G, Yamakido M (1994) Incidence of diabetes mellitus and its risk factors in Japanese-Americans living in Hawaii and Los Angeles. 15th IDF Congress, abstract 08A30P0707

6. Bergström RW, Newell-Morris L, Leonetti DL, Shuman WP, Wahl PW, Fujimoto WY (1990) Association of ele- 
vated fasting $C$-peptide and increased intra-abdominal fat distribution with development of NIDDM in JapaneseAmerican men. Diabetes 39: 104-111

7. King H, Zimmet P, Raper LR, Balkau B (1984) The natural history of impaired glucose tolerance in the Micronesian population of Nauru: a 6-year follow-up study. Diabetologia $26: 39-43$

8. Lundgren $\mathbf{H}$, Bengtsson $\mathrm{C}$, Blohme $\mathrm{G}$, Lapidus I, Waldenström J (1990) Fasting serum insulin concentration and early insulin response as risk determinants for developing diabetes. Diabet Med 7: 407-413

9. Skarfors ET, Selinus KI, Lithell HO (1991) Risk factors for developing non-insulin-dependent diabetes: a 10 year follow-up of men in Uppsala. BMJ 303: 755-760

10. Charles MA, Fontbonne A, Thibult N, Eschwege E (1991) Risk factors for NIDDM in white population. Paris Prospective Study. Diabetes 40: 796-799

11. Martin BD, Warram JH, Krolewski AS, Bergman RN, Soeldner JS, Kahn CR (1992) Role of glucose and insulin resistance in development of type II diabetes mellitus: results of 25-year follow-up study. Lancet 340: 925-929

12. Bouchard C, Tremblay A, Despres J-P et al. (1990) The response to long-term overfeeding in identical twins. $N$ Engl J Med 322: 1477-1482

13. Faccini FS, Hollenbeck CB, Jeppesen J, Chen YD, Reaven GM (1992) Insulin resistance and cigarrette smoking. Lancet 339: 1128-1130

14. Ferrannini E, Buzzigoli G, Bonadonna R et al. (1987) Insulin resistance in essential hypertension. N Engl J Med 317: $350-357$

15. Eriksson J, Franssila-Kallunki A, Ekstrand A et al. (1989) Early metabolic defects in persons at increased risk for non-insulin-dependent diabetes mellitus. $\mathrm{N}$ Engl J Med 321: 337-343

16. Haffner SM, Stern MP, Hazuda HP, Mitchell BD, Patterson JK (1988) Increased insulin concentrations in nondiabetic offspring of diabetic parents. N Engl J Med 319: 1297-1301

17. DeFronzo RA, Tobin JD, Andres R (1979) Glucose clamp technique: a method for quantifying insulin secretion and resistance. Am J Physiol 237: E214-E223

18. Rosenthal M, Haskell WL, Solomon R, Widström A, Reaven GM (1983) Demonstration of a relationship between physical training and insulin-stimulated glucose utilization in normal humans. Diabetes 32: 408-411

19. Kelley DE, Mokan M, Mandarino LJ (1992) Intracellular defects in glucose metabolism in obese patients with NIDDM. Diabetes 41: 698-706

20. Nuutila P, Knuuti MJ, Heinonen OJ et al. (1994) Different alterations in the insulin-stimulated glucose uptake in the athlete's heart and skeletal muscle. J Clin Invest 93: 2267-2274

21. Nuutila P, Mäki M, Laine H, Knuuti JM, Ruotsalainen U, Luotolahti M, Haaparanta M, Solin O, Jula A, Koivisto VA, Voipio-Pulkki L-M, Yki-Järvinen H (1995) Insulin action on heart and skeletal muscle glucose uptake in essential hypertension. J Clin Invest 96: 1003-1009

22. Dengel DR, Pratley RE, Hagberg JM, Golberg AP (1994) Impaired insulin sensitivity and maximal responsiveness in older hypertensive men. Hypertension 23: 320-324

23. Lillioja S, Mott DM, Zawadzki JK et al. (1987) In vivo insulin action is a familial characteristic in nondiabetic Pima Indians. Diabetes 36: 1329-1335

24. Nyholm B, Mengel A, Nielsen S, Moller N, Schmitz O (1994) The insulin resistance of relatives of type 2 diabetic subjects is significantly related to a reduced $\mathrm{VO}_{2}$ max. Diabetologia 37 [Suppl 1]: A28 (Abstract)
25. Yki-Järvinen H, Koivisto VA (1983) Effect of body composition on insulin sensitivity. Diabetes 32: 965-969

26. Yki-Järvinen $\mathrm{H}$, Koivisto VA, Taskinen M, Nikkilä E (1984) Glucose tolerance, plasma lipoproteins and tissue lipoprotein lipase activities in body builders. Eur J Appl Physiol 53: 253-259

27. Kannel WB, Abbott RD (1987) Incidence and prognosis of myocardial infarction in women: the Framingham study. In: Eaker ED, Packard B, Wenger-NK, Clarkson TB, Tyroler HA (eds) Coronary heart disease in women. Haymarket-Doyma, New York, pp 208-214

28. Björntorp P (1993) Androgens, the metabolic syndrome and non-insulin-dependent diabetes mellitus. Ann NY Acad Sci 676: 242-252

29. Krotkiewski M, Björntorp P, Sjöstrom L, Smith U (1983) Impact of obesity on metabolism in men and women: importance of regional adipose tissue distribution. J Clin Invest $72: 1150-1162$

30. Modan M, Halkin H, Karasik A, Lusky A (1987) Elevated serum uric acid- a facet of hyperinsulinaemia. Diabetologia 30: 713-718

31. Yki-Järvinen H (1984) Sex and insulin sensitivity. Metabolism 33: 1011-1015

32. Åstrand I(1960) Aerobic work capacity in men and women with special reference to age. Acta Physiol Scand 49: 45-60

33. Nuutila P, Knuuti MJ, Mäki M et al. (1995) Gender and insulin sensitivity in the heart and in skeletal muscles. Studies using positron emission tomography. Diabetes 44: 31 36

34. Reis SE, Gloth ST, Blumenthal RS et al. (1994) Ethinyl estradiol acutely attenuates abnormal coronary vasomotor responses to acetylcholine in postmenopausal women. Circulation 89: 52-60

35. Holmäng A, Svedberg J, Jennische E, Björntorp P (1992) Effects of testosterone on muscle insulin sensitivity and morphology in female rats. Am J Physiol 259: E555-E560

36. Ravussin E (1993) Energy metabolism in obesity. Studies in the Pima Indians. Diabetes Care 16: 232-238

37. Lillioja S, Young AA, Culter CL et al. (1987) Skeletal muscle capillary density and fiber type are possible determinants of in vivo insulin resistance in man. J Clin Invest 80: $415-424$

38. Lithell H, Lundqvist G, Nygaard E, Vessby B, Saltin B (1981) Body weight, skeletal muscle morphology, and enzyme activities in relation to fasting serum insulin concentration and glucose tolerance in 48-year-old men. Diabetes 30: 19-25

39. Holmäng A, Brezinska Z, Björntorp P (1993) Effects of hyperinsulinemia on muscle fiber composition and capillarization in rats. Diabetes 42: 1073-1081

40. Castillo C, Bogardus C, Bergman R, Thuillez P, Lillioja S (1994) Interstitial insulin concentrations determine glucose uptake rates but not insulin resistance in lean and obese men. J Clin Invest 93: 10-16

41. Vague J (1947) La differentiation sexuelle. Facteur determinant des formes de l'obesite. Presse Med 55: 339

42. Peiris AN, Struve MF, Mueller RA, Lee MB, Kissebah AH (1988) Glucose metabolism in obesity: influence of body fat distribution. J Clin Endocrinol Metab 67: 760-767

43. Lönnqvist F, Thörne A, Nilsell K, Hoffstedt J, Arner P (1995) A pathogenetic role of visceral $\beta_{3}$-adrenoreceptors in obesity. J Clin Invest 95: 1109-1116

44. Björntorp P (1988) Abdominal obesity and the development of non-insulin-dependent diabetes mellitus. Diabetes Metab Rev 4: 615-622

45. Del Prato S, Leonetti F, Simonson DC, Sheehan P, Matsuda M, DeFronzo RA (1994) Effect of sustained physio- 
logic hyperinsulinaemia and hyperglycaemia on insulin secretion and insulin sensitivity in man. Diabetologia 37: 1025-1035

46. Knowler WC, Pettitt DJ, Savage RJ, Bennett PH (1981) Diabetes incidence in Pima Indians: contributions of obesity and parental diabetes. Am J Epidemiol 113: 144-156

47. Garner LI, Stern MP, Haffner SM, Gaskill SP, Hazuda HP, Relethford JH (1984) Prevalence of diabetes in Mexican Americans. Relationship to percent of gene pool derived from native American sources. Diabetes 33: 86-92

48. Lillioja S, Nyomba B, Saad MF, Ferraro R, Castillo C, Bennett PH, Bogardus C (1991) Exaggerated early insulin release and insulin resistance in a diabetes-prone population: a metabolic comparison of Pima Indians and Caucasians. J Clin Endocrinol Metab 73: 866-876

49. Banerji MA, Chaiken RL, Gordon D, Kral JG, Lebovitz HE (1995) Does intra-abdominal adipose tissue in black men determine whether NIDDM is insulin-resistant or insulin-sensitive? Diabetes 44: 141-146

50. Bonora E, Del Prato S, Bonadonna R et al. (1992) Total body fat content and fat topography are associated differently with in vivo glucose metabolism in nonobese and obese nondiabetic women. Diabetes 41: 1151-1159

51. DeFronzo RA (1992) Pathogenesis of type 2 (non-insulindependent) diabetes mellitus: a balanced overview. Diabetologia 35: 389-397

52. Mitrakou A, Kelley D, Veneman Tet al. (1990) Contribution of abnormal muscle and liver metabolism to postprandial hyperglycemia in NIDDM. Diabetes 39: 13811390

53. Mitrakou A, Kelley D, Mokan M et al. (1992) Role of reduced suppression of glucose production and diminished early insulin release in impaired glucose tolerance. $\mathrm{N}$ Engl J Med 326: 22-29

54. DeFronzo RA, Jacot E, Jequier E, Maeder E, Wahren J, Felber JP (1981) The effect of insulin on the disposal of intravenous glucose. Results from indirect calorimetry and hepatic and femoral venous catheterization. Diabetes 30: 1000-1007

55. Scheinberg P, Stead EAJ (1949) The cerebral blood flow in male subjects as measured by the nitrous oxide technique. Normal values for blood flow, oxygen utilization, glucose utilization and peripheral resistance, with observations of the effect of tilting and anxiety. J Clin Invest 28: $1149-1163$

56. Reinmuth OM, Scheinberg P, Bourne B (1965) Total cerebral blood flow and metabolism. Arch Neurol 12: 49-66

57. Rowe GG, Maxwell GM, Castillo CA, Freeman DJ, Crumpton CW (1959) A study in man of cerebral blood flow and cerebral glucose, lactate and pyruvate metabolism before and after eating. J Clin Invest 38: 2154-2158

58. Gutniak M, Blomqvist G, Widen L, Stone-Elander S, Hamberger B, Grill V (1990) D-[U- ${ }^{11}$ C]glucose uptake and metabolism in the brain of insulin-dependent diabetic subjects. Am J Physiol 258: E805-E812

59. Shulman G, Rothman D, Jue T, Stein P, DeFronzo RA, Shulman R (1990) Quantitation of muscle glycogen synthesis in normal subjects and subjects with non-insulin-dependent diabetes by ${ }^{13} \mathrm{C}$ nuclear magnetic resonance spectroscopy. N Engl J Med 322: 223-228

60. Wisneski JEG, Neese RA, Gruneke LD, Morris DL, Craig JC (1985) Metabolic fate of extracted glucose in human myocardium. J Clin Invest 76: 1819-1827

61. Nuutila P, Koivisto VA, Knuuti J et al. (1992) The glucosefree fatty acid cycle operates in human heart and skeletal muscle in vivo. J Clin Invest 89: 1767-1774
62. Nuutila P, Knuuti J, Ruotsalainen U et al. (1993) Insulin resistance is localized to skeletal muscle but not heart muscle in type 1 diabetes. Am J Physiol 264: E756-E762

63. Del Prato S, Bonadonna R, Bonora E et al. (1993) Characterization of the cellular defects of insulin action in type 2 (non-insulin-dependent) diabetes mellitus. J Clin Invest 91: 484-494

64. Yki-Järvinen H (1993) Fate of glucose in insulin resistant states. In: Crepaldi G, Tiengo A, Manzato E (eds) Diabetes, obesity and hyperlipidemia: V. The plurimetabolic syndrome. Elsevier Science Publishers B. V. Amsterdam, pp 75-82

65. Felber JP, Thiébaud D, Maeder E, Jéquier E, Hendler R, DeFronzo RA (1983) Effect of somatostatin-induced insulinopenia on glucose oxidation in man. Diabetologia 25: $325-330$

66. Groop LC, Kankuri M, Schalin-Jäntti C et al. (1993) Association between polymorphism of the glycogen synthase gene and non-insulin-dependent diabetes mellitus. N Engl J Med 328: 10-14

67. Baron AD (1994) Hemodynamic actions of insulin. Am J Physiol 267: E187-E202

68. Laakso M, Edelman SV, Brechtel G, Baron AD (1990) Decreased effect of insulin to stimulate skeletal muscle blood flow in obese man. J Clin Invest 85: 1844-1882

69. Utriainen T, Malmström R, Mäkimattila S, Yki-Järvinen $\mathrm{H}$ (1995) Methodological aspects, dose-response characteristics and causes of interindividual variation in insulin stimulation of limb blood flow in normal subjects. Diabetologia 38: $555-564$

70. Baron AD, Laakso M, Brechtel G, Edelman SV (1991) Mechanisms of insulin resistance in insulin-dependent diabetes mellitus: a major role for reduced skeletal muscle blood flow. J Clin Endocrinol Metab 73: 637-643

71. Laakso M, Edelman SV, Brechtel G, Baron AD (1992) Impaired skeletal muscle blood flow in patients with NIDDM. Diabetes 41: 1076-1083

72. Baron AD, Brechtel-Hook G, Johnson A, Hardin D (1993) Skeletal muscle blood flow. A possible link between insulin resistance and blood pressure. Hypertension 21: 129-135

73. Yki-Järvinen H, Sahlin K, Ren JM, Koivisto VA (1990) Localization of the rate-limiting defect for glucose disposal in skeletal muscle of insulin-resistant type 1 diabetic patients. Diabetes 39: 157-167

74. DeFronzo RA, Gunnarson R, Bjorkman O, Olsson M, Wahren $\mathbf{J}$ (1985) Effects of insulin on peripheral and splanchnic glucose metabolism in noninsulin-dependent (type II) diabetes mellitus. J Clin Invest 76:149-155

75. Dela F, Larsen JJ, Mikines KJ, Galbo H (1995) Normal effect of insulin to stimulate leg blood flow in NIDDM. Diabetes $44: 221-226$

76. Natali A, Santoro D, Palombo C, Cerri M, Ghione M, Ferrannini E (1991) Impaired insulin action on skeletal muscle metabolism in essential hypertension. Hypertension 17: $170-178$

77. Baron AD, Steinberg H, Brechtel G, Johnson A (1994) Skeletal muscle blood flow independently modulates insulin-mediated glucose uptake. Am J Physiol 266: E248E253

78. Natali A, Bonadonna R, Santoro D et al. (1994) Insulin resistance and vasodilatation in essential hypertension. Studies with adenosine. J Clin Invest 94: 1570-1576

79. Warram JH, Martin BC, Krolewski AS, Soeldner JS, Kahn RC (1990) Slow glucose removal rate and hyperinsulinemia precede the development of type II diabetes in the offspring of diabetic parents. Ann Intern Med 113: 909-915 
80. Helmrich SP, Ragland DR, Leung RW, Paffenbarger RS (1991) Physical activity and reduced occurrence of non-insulin-dependent diabetes mellitus. N Engl J Med 325: 147152

81. Eriksson K-F, Lindgärde F (1991) Prevention of type 2 (non-insulin-dependent) diabetes mellitus by diet and physical exercise. The 6-year Malmö feasibility study. Diabetologia 34: 891-898

82. Shaten J, Smith GD, Kuller LH, Neaton JD (1993) Risk factors for the development of type II diabetes among men enrolled in the usual care group of the multiple risk intervention trial. Diabetes Care 16: 1331-1339

83. Vaag A, Henriksen JE, Beck-Nielsen H (1992) Decreased insulin activation of glycogen synthase in skeletal muscles in young nonobese Caucasian first-degree relatives of patients with non-insulin-dependent diabetes mellitus. J Clin Invest 89: 782-788

84. Vaag A, Henriksen JE, Madsbad S, Holm N, Beck-Nielsen $H$ (1995) Insulin secretion, insulin action, and hepatic glucose production in identical twins disconcordant for non-insulin-dependent diabetes mellitus. J Clin Invest 95: 690-698

85. Gulli G, Ferrannini E, Stern M, Haffner S, DeFronzo RA (1992) The metabolic profile is fully established in the glucose tolerant offspring of two Mexican American non-insulin-dependent diabetic parents. Diabetes 41: 1575-1586

86. Harris MI, Hadden WC, Knowler WC, Bennett PH (1987) Prevalence of diabetes and impaired glucose tolerance and plasma glucose levels in U.S. population aged 2074 years. Diabetes $36: 523-534$

87. Bonora E, Gulli G, Bonadonna R, Del Prato S, Solini A, DeFronzo RA (1995) Insulin sensitivity is not impaired in Mexican-American women without a family history of diabetes. Diabetes Care 18: 825-833

88. Kadowaki T, Miyake Y, Hagura R et al. (1984) Risk factors for worsening to diabetes in subjects with impaired glucose tolerance. Diabetologia 26: 44-49

89. Lillioja S, Mott DM, Spraul M et al. (1993) Insulin resistance and insulin secretory dysfunction as precursors of non-insulin-dependent diabetes mellitus. N Engl J Med 329: 1988-1992

90. Hara H, Egusa G, Yamakido M, Kawate R (1994) The high prevalence of diabetes mellitus and hyperinsulinemia among the Japanese-Americans living in Hawaii and Los Angeles. Diabetes Res Clin Pract. [Supp1]: S37-S42

91. Saad MF, Knowler WC, Pettitt DJ, Nelson RG, Mott DM, Bennett PH (1988) The natural history of impaired glucose tolerance in the Pima Indians. N Engl J Med 319: 1500-1506

92. Lindstedt G, Lundberg P-A, Lapidus L, Lundgren H, Bentsson C, Björntorp P (1991) Low sex-hormone-binding globulin concentration as independent risk factor for development of NIDDM. Diabetes 40: 123-128

93. Keen H, Jarrett RJ, McCartney P (1982) The ten-year follow-up of the Bedford survey (1962-1972): glucose tolerance and diabetes. Diabetologia 22: 73-78

94. Ohlson L-O, Larsson B, Svärdsudd K et al. (1985) The influence of body fat distribution on the incidence of diabetes mellitus. 13.5 years of follow-up of the participants in the study of men born in 1913. Diabetes 34: 1055-1058

95. Frisch RE, Wyshak G, Albright TE, Albright NL, Schiff L (1986) Lower prevalence of diabetes in female former college athletes compared with nonathletes. Diabetes 35: 1101-1105

96. Modan M, Karasik A, Halkin H et al. (1986) Effect of past and concurrent body mass index on prevalence of glucose intolerance and type 2 (non-insulin-dependent) diabetes and on insulin response. The Israel study of glucose intolerance, obesity and hypertension. Diabetologia 29: 82-89

97. Manson J, Rimm EB, Stampfer MJ et al. (1991) Physical activity and incidence of non-insulin-dependent diabetes mellitus in women. Lancet 338: 774-778

98. Serjeantson SW, Owerbach D, Zimmet P, Nerup J, Thoma K (1983) Genetics of diabetes in Nauru: effects of foreign admixture, HLA antigens and insulin-gene-linked polymorphism. Diabetologia 25: 13-17

99. Manson JE, Nathan DM, Krolewski AS, Stapfer MJ, Willett WC, Hennekens CH (1992) A prospective study of exercise and incidence of diabetes among US male physicians. JAMA 268: 63-67

100. Everhart JE, Pettitt DJ, Bennett PH, Knowler WC (1992) Duration of obesity increases the incidence of NIDDM. Diabetes 41: 235-240

101. Pimenta W, Korytkowski M, Mitrakou A et al. (1995) Pancreatic beta-cell dysfunction as the primary genetic lesion in NIDDM. Evidence from studies in normal glucose-tolerant individuals with a first-degree NIDDM relative. JAMA 273: 1855-1861

102. Tuomi TM, Groop LC, Zimmet PZ, Rowley MJ, Knowles W, Mackay IR (1993) Antibodies to glutamic acid decarboxylase reveal latent autoimmune diabetes mellitus in adults with non-insulin-dependent onset of disease. Diabetes $42: 359-362$

103. DeFronzo RA, Bonadonna RC, Ferrannini E (1992) Pathogenesis of NIDDM. A balanced overview. Diabetes Care 15: 318-368

104. DeFronzo RA, Hendler R, Simonson D (1982) Insulin resistance is a prominent feature of insulin-dependent diabetes. Diabetes 31: 795-801

105. Yki-Järvinen H, Koivisto VA (1986) Natural course of insulin resistance in type 1 diabetes. $N$ Engl J Med 315: 224-230

106. Yki-Järvinen H, Kiviluoto T, Taskinen M-R (1986) Insulin resistance is a prominent feature of patients with pancreatogenic diabetes. Metabolism 35: 718-727

107. Yki-Järvinen H, Koivisto VA (1984) Insulin sensitivity in newly diagnosed type 1 diabetics following ketoacidosis and after a 3 month insulin therapy. J Clin Endocrinol Metab 59: 371-378

108. Lager I, Lonnroth P, Von Shenck H, Smith U (1983) Reversal of insulin resistance in type 1 diabetes after treatment with continuous subcutaneous insulin infusion. BMJ 287: 1001-1004

109. Yki-Järvinen H, Koivisto V (1984) Continuous subcutaneous insulin infusion therapy decreases insulin resistance in type 1 diabetes. J Clin Endocrinol Metab 58: 659-666

110. Beck-Nielsen H, Richelsen B, Hasling C, Nielsen OH, Heding L, Sorensen NS (1984) Improved in vivo insulin effect during continuous subcutaneous insulin infusion in patients with IDDM. Diabetes 33: 832-837

111. Rossetti L, Giaccari A, DeFronzo RA (1990) Glucose toxicity. Diabetes Care 13: 610-630

112. Bogardus C, Lillioja S, Howard BV, Reaven G, Mott D (1984) Relationship between insulin secretion, insulin action, and fasting plasma glucose concentration in nondiabetic and non-insulin-dependent diabetic subjects. J Clin Invest 77: 1238-1246

113. Yki-Järvinen H, Nikkilä E, Helve E, Taskinen M-R (1988) Clinical benefits and mechanisms of a sustained response to intermittent insulin therapy in type 2 diabetic patients with secondary drug failure. Am J Med 84: 185-192

114. Yki-Järvinen H, Taskinen M-R, Kiviluoto T et al. (1984) Site of insulin resistance in type 1 diabetes: insulin-mediated glucose disposal in vivo in relation to insulin binding 
and action in adipocytes in vitro. $\mathrm{J}$ Clin Endocrinol Metab 59: 1183-1192

115. Yki-Järvinen H, Helve E, Koivisto VA (1987) Hyperglycemia decreases glucose uptake in type 1 diabetes. Diabetes 36: 892-896

116. Vuorinen-Markkola $H$, Koivisto VA, Yki-Järvinen $H$ (1992) Mechanisms of hyperglycemia-induced insulin resistance in whole body and skeletal muscle of type 1 diabetic patients. Diabetes 41: $571-580$

117. Rossetti L, Smith D, Shulman GI, Papachristou D, DeFronzo RA (1987) Correction of hyperglycemia with phlorizin normalizes tissue sensitivity to insulin in diabetic rats. J Clin Invest 79: 1510-1515

118. Rossetti L, Shulman G, Zawalich W, DeFronzo RA (1987) Effect of chronic hyperglycemia on in vivo insulin secretion in partially pancreatectomized rats. J Clin Invest 80: 1037-1044
119. Yki-Järvinen H (1992) Glucose toxicity. Endocr Rev 13: $415-431$

120. Gerich JE (1989) Oral hypoglycemic agents. N Engl J Med 321: 1231-1245

121. Yki-Järvinen H, Nikkilä EA (1985) Ethanol decreases glucose utilization in healthy man. J Clin Endocrinol Metab 61: 941-945

122. Yki-Järvinen $\mathrm{H}$, Koivisto VA, Ylikahri R, Taskinen M-R (1988) Acute effects of ethanol and acetate on glucose kinetics in normal man. Am J Physiol 254: E175-E180

123. Yki-Järvinen H, Taskinen M-R (1988) Interrelationship among insulin's antilipolytic and glucoregulatory effects and plasma triglycerides in nondiabetic and diabetic patients with endogenous hypertriglyceridemia. Diabetes 37: $1271-1278$ 